\title{
KEMAMPUAN PERAWAT DALAM MEMBERIKAN ASUHAN KEPERAWATAN MENJADI ISSUE PENTING DALAM MEWUJUDKAN KESELAMATAN DAN KEPUASAN PASIEN
}

\author{
Friderikus Zebua \\ zebuafriderikus@gmail.com
}

\section{LATAR BELAKANG}

Perawat sebagai ujung tombak pemberi pelayanan kesehatan adalah hal yang penting untuk dikaji dalam rangka mempertahankan serta meningkatkan mutu pelayanan kesehatan. Kinerja yang baik adalah jembatan dalam menjawab kualitas pelayanan kesehatan yang diberikan terhadap pasien baik yang sakit ataupun yang sehat. Perawat harus sadar akan perannya sehingga bisa secara aktif ikut berpartisipasi agar mewujudkan keselamatan pasien. Hal ini juga tidak akan mencapai optimal jika hanya dengan kerja keras dari perawat saja, tetapi didukung dengan sarana prasarana, manajemen rumah sakit dan tenaga kesehatan lainnya. Joint Comission International (JCI) membagi beberapa sasaran keselamatan pasien meliputi komponen identifikasi pasien, komponen penggunaan komunikasi efektif, komponen pemakaian obat dengan kewaspadaan tinggi, komponen ketepatan lokasi operasi, prosedur dan dan pasien yang akan dibedah, komponen mengurangi resiko terinfeksi, serta komponen menilai resiko pasien jatuh (JCI, 2016).

Budaya keselamatan pasien adalah sebuah kewajiban dan tanggung jawab seluruh pegawai. Pengawai merupakan bagian dari organisasi yang berupa ujung tombak dalam budaya keselamatan pasien. Di samping itu organisasi rumah sakit sebagai pemberi pelayanan kesehatan harus bisa menerima keselamatan sebagai nilai baru dalam budaya organisasi dengan komitmen berani berubah, berubah dalam arti blaming cultur menjadi safety culture. Salah satu masalah umum yang terjadi dalam pemberian pelayanan di bidang kesehatan merupakan masalah yang berkaitan dengan keselamatan pasien.Penelitian yang diterapkan oleh IBEAS (Iberoamerican Study of Adverse Events) pada tahun 2011 yang dilakukan di 58 rumah sakit yang tersebar di Argentina, Colombia, Costa Rica, Mexico dan Peru serta melibatkan 11.379 pasien rawat inap mendapatkan hasil dari jumlah tersebut,1.191 memiliki setidaknya satu insiden keselamatan pasien yang berkaitan dengan perawatan yang diterima dari pelayanan kesehatan. 
Patient safety yaitu prioritas, isu penting dan global dalam pelayanan kesehatan. Patient safety adalah komponen penting dan vital dalam asuhan keperawatan yang berkualitas Hal ini menjadi penting karena Patient safety adalah suatu langkah untuk memperbaiki mutu pelayanan dalam memberikan asuhan keperawatan. Inti dari patient safety yakni penghindaran, pencegahan dan perbaikan dari kejadian yang tidak diharapkan serta mengatasi cedera-cedera dari proses pelayanan kesehatan. Sehingga, program utama patient safety adalah suatu usaha agar menurunkan angka kejadian tidak diharapkan (KTD) yang sering terjadi pada pasien selama dirawat di rumah sakit yang sangat merugikan baik pasien ataupun pihak rumah sakit.

Kesalahan medis dan efek samping sudah menjadi perhatian serius dalam beberapa tahun terakhir bagi pembuat kebijakan kesehatan dan penyedia layanan kesehatan dunia. Menurut statistik tahunan, di Amerika Serikat sekitar 98.000 masalah kematian pasien dilaporkan karena kesalahan medis. Program pengamatan lima tahun yang dilaksanakan oleh Baldo et al. (2002) mengungkapkan bahwa perawat bertanggung jawab untuk 78\% dari efek samping. Selain itu penelitian juga membuktikan bahwa kematian akibat cidera medis 50\% sebenarnya bisa dicegah. Komoditas utama dalam pelayanan kesehatan di rumah sakit yakni pelayanan keperawatan.

Hal ini bukan mengesampingkan pelayanan medis, tetapi mayoritas perawatan yang diperlukan oleh pasien yaitu asuhan keperawatan budaya keselamatan pasien merupakan persepsi yang dibagikan di antara anggota organisasi bertujuan untuk melindungi pasien dari kesalahan tata laksana ataupun cidera akibat intervensi. Patient safety yaitu hal penting dalam pelayanan kesehatan. Rumah sakit sebagai institusi pelayanan kesehatahuan harus bisa memberikan jaminan terhadap patient safety dalam setiap pelayanan yang diberikan. Keselamatan adalah komponen yang paling dasar, vital dan utama dari kualitas pelayanan kesehatan.

\section{METODE}

Metode penulisan yang digunakan yakni dengan metode deskriptif,. yaitu dilakukan dengan teknik pengumpulan data atau informasi dengan melakukan analisis, eksplorasi, kajian bebas (literatur review) yang relevan serta berfokus pada tema yaitu kemampuan perawat menjadi issue penting dalam mewujudkan keselamatan pasien di Rumah Sakit. Adapun sumber yang digunakan dalam penulisan ini adalah menggunakan sumber dari buku teks, dan jurnal dengan memasukkan kata kunci Perencanaan dalam proses keperawatan. Adapun referensi dari buku 
teks, dan jurnal yang saya gunakan yaitu dengan menggunakan jurnal yang diterbitkan pada 10 tahun terakhir ( dengan tahun paling tua 2010).

\section{HASIL}

Rumah Sakit (RS) adalah institusi pelayanan kesehatan bagi masyarakat dengan karateristik tersendiri yang dipengaruhi oleh perkembangan ilmu pengetahuan kesehatan, kemajuan teknologi, dan kehidupan sosial ekonomi masyarakat yang harus tetap mampu meningkatkan pelayanan yang lebih bermutu dan terjangkau oleh masyarakat agar terwujud derajat kesehatan yang setinggi- tingginya, seperti yang dijelaskan dalam UndangUndang Kesehatan Nomor 36 Tahun 2009 dan Undang-Undang Rumah Sakit Nomor 44 Tahun 2009 bahwa rumah sakit wajib melaksanakan pelayanan kesehatan yang aman, bermutu, anti diskriminasi dan efektif, dengan mengutamakan kepentingan pasien. Rumah sakit wajib memenuhi hak pasien memperoleh keamanan dan keselamatan selama dalam perawatan di rumah sakit.

(Permenkes RI Nomor 1961/Menkes/2011). Keselamatan Pasien (patient safety) merupakan isu global dan nasional bagi rumah sakit, komponen penting dari mutu layanan kesehatan, prinsip dasar dari pelayanan pasien dan komponen kritis dari manajemen mutu (WHO, 2014). Ada lima isu penting yang terkait dengan keselamatan (safety) di rumah sakit yaitu: keselamatan pasien. (patient safety), keselamatan pekerja atau petugas kesehatan, keselamatan bangunan dan peralatan di rumah sakit, keselamatan lingkungan (green productivity) dan keselamatan bisnis rumah sakit.

Ke lima aspek keselamatan tersebut sangatlah penting untuk dilaksanakan di setiap rumah sakit. Harus diakui kegiatan institusi rumah sakit dapat berjalan apabila ada pasien. Karena itu keselamatan pasien merupakan prioritas utama untuk dilaksanakan dan hal tersebut terkait dengan isu mutu dan citra perumahsakitan (Depkes, 2015, p.17)

Dari metode literature review yang digunakan didapatkan bahwa penerapan keselamatan perawat penting dilakukan pada pasien di rumah sakit terkait issue pasien safety. Yang dimaksud dari Isu keselamatan pasien melahirkan paradigma baru tentang mutu pelayanan. Mutu pelayanan yang baik saja tidak cukup berarti bagi pasien tanpa memperhatikan bagaimana derajat unsur resiko serta keselamatan yang diterima oleh pasien. Hubungan antara kepuasan kerja dengan kesehatan fisik serta mental. Supaya menciptakan tempat kerja yang aman, sehat, 
bebas dari pencemaran lingkungan, sehingga bisa mengurangi dan atau bebas dari kecelakaan kerja dan penyakit akibat kerja yang pada akhirnya bisa meningkatkan efisiensi dan produktivitas kerja.

\section{PEMBAHASAN}

Proses keperawatan adalah aktivitas yang mempunyai maksud yaitu praktik keperawatan yang dilakukan dengan cara yang sistematik. Selama melaksanakan proses keperawatan, perawat enggunakan dasar pengetahuan yang komprehensif untuk mengkaji status kesehatan klien, membuat penilaian yang bijaksana dan mendiagnosa, mengidentifikasi hasil akhir kesehatan klien dan merencanakan, menerapkan dan mengevaluasi tindakan keperawatan yang tepat guna mencapai hasil akhir tersebut (Dermawan, 2012).

Keselamatan pasien rumah sakit merupakan suatu sistem dimana rumah sakit membuat asuhan pasien lebih aman. Sistem tersebut meliputi asesmen resiko, identifikasi serta pengelolaan hal yang berhubungan dengan risiko pasien. pelaporan dan analisis insiden, kemampuan belajar dari insiden dan tindak lanjut serta implementasi solusi agar meminimalkan timbulnya resiko dan mencegah terjadinya cedera. Insiden cidera dapat juga terjadi dari aspek seperti kesalahan pemberian obat, kegagalan komunikasi, infeksi yang berkaitan dengan pelayanan kesehatan, kesalahan akibat melaksanakan suatu tindakan serta tidak mengambil tindakan yang seharusnya diambil.

Perawat adalah salah satu tenaga kesehatan yang memegang peranan penting dalam pelayanan kesehatan dirumah sakit. Perawat memiliki peran memberikan asuhan keperawatan yang berkualitas karena.perawat berinteraksi langsung selama 24.jam dengan pasien, serta jumlah perawat.yang mendominasi sehingga perawat harus mampu memberikan pelayanan.keperawatan yang bermutu. Oleh karena itu.pelayanan keperawatan memiliki kontribusi.yang besar dalam meningkatkan mutu pelayanan rumah sakit.Isu keselamatan pasien menciptakan.paradigma baru tentang mutu pelayanan. Mutu pelayanan yang baik saja tidak cukup.berarti bagi pasien tanpa memperhatikan bagaimana derajat unsur resiko serta keselamatan yang diterima oleh pasien Tinggi rendahnya mutu sebanding dengan tingkat ketersediaan fasilitas pelayanan, agar mencapai keseimbangan terbaik antara risiko dan manfaat keselamatan yang diterima oleh pasien. 
Dalam Undang-Undang Nomor 36 Tahun 2009 tentang Kesehatan, Pasal 165 pengelola tempat kerja wajib melakukan segala bentuk upaya kesehatan melalui upaya pencegahan, peningkatan, pengobatan, serta pemulihan bagi tenaga kerja. Berdasarkan pasal tersebut maka pengelola tempat kerja di Rumah Sakit mempunyai kewajiban agar menyehatkan para tenaga kerjanya. Salah satunya yaitu melalui upaya kesehatan kerja disamping keselamatan kerja. Rumah Sakit wajib menjamin kesehatan serta keselamatan baik terhadap pasien, penyedia layanan atau pekerja ataupun masyarakat sekitar dari berbagai potensi bahaya di Rumah Sakit. Oleh karena itu, Rumah Sakit dituntut agar melaksanakan Upaya Kesehatan dan Keselamatan Kerja (K3) yang dilaksanakan secara terintegrasi dan menyeluruh sehingga risiko terjadinya Penyakit Akibat Kerja (PAK) dan Kecelakaan Akibat Kerja (KAK) di Rumah Sakit bisa dihindari. Penyakit akibat kerja di rumah sakit dapat menyerang semua tenaga kerja baik medis ataupun non medis. Sehingga sasaran utama K3RS yakni tenaga medis, tenaga non medis, pasien pengunjung / pengantar pasien, serta masyarakat sekitar Rumah Sakit.

Bahayanpotensial yang bisa menyebabkan penyakit akibat kerja (PAK) yang terjadi di rumah sakit, umumnya berkaitan dengan faktor biologi (kuman patogen yang umumnya berasal dari pasien), faktor kimia (pemaparan dalam dosis kecil namun terus menerus seperti antiseptik pada kulit, gas anestesi pada hati), faktor ergonomi (tata cara duduk, tata cara mengankat pasien), faktor fisik dalam dosis kecil yang terus menerus (suhu udara panas, listrik tegangan tinggi, dan radiasi), faktor psikologis (hubungan kerja antar karyawan maupun atasan serta tata cara kerja di kamar bedah,.dibagian penerimaan pasien, di unit gawat darurat dan ruang perawatan.) Karyawan sebagai aset penting rumah sakit wajib dijaga dan dibina agar selalu dalam kondisi yang sehat dan bebas dari pengaruh negatif yang disebabkan oleh bahaya di tempat kerja. Berdasarkan tempat kerja karyawan terbagi menjadi 4 zona risiko yaitu zona risiko rendah, zona risiko sedang, zona risiko tinggi dan zona risiko sangat tinggi. Zona risiko tinggi yakni karyawan yang bekerja pada bagian ruangan operasi, ruang bedah mulut, ruang perawatan gigi, ruang rawat gawat darurat, ruang bersalin serta ruang patologi. Petugas medis di ruang IGD antara lain perawat serta dokter. Perawat yakni petugas medis pertama yang menangani pasien sebelum dokter. Dengan beban kerja yang tinggi di ruang IGD memungkinkan terjadinya stress kerja para perawat IGD. Selain stress kerja, keluhan muskuloskeletal juga sering dialami oleh perawat IGD. Berdasarkan hal tersebut maka perawat lebih berisiko tinggi terjadinya penyakit akibat kerja di ruang IGD bila.dibandingkan dengan dokter..Seperti yang tercantum dalam Kepmenkes RI No. 
1087 Tahun 2010 tentang standart kesehatan dan keselamatan kerja (K3) di Rumah Sakit bahwa penyesuaian terhadap peralatan kerja SDM dikatkan sudah diterapkan apabilah telah melakukan :

1.Identifikasi serta penilaian risiko ergonomi terhadap perlatan kerja dan SDM Ruma Sakit.

2. Membuat program pelaksanaan kegiatan, mengevaluasi serta mengendalik resiko ergonomik

Menurut KKPRS 2008 Tujuh langkah menuju keselamatan pasien bagi staf rumah sakit dilakukan dengan tujuh cara yaitu :

a. Membangun kesadaran akan nilai keselamatan pasien dengan membuat kebijakan rumah sakit terkait peran serta tanggung jawab individu bila terjadi insiden

b. Membangun komitmen yang kuat tentang keselamatan pasien dengan memasukan keselamatan pasien sebagai agenda kerja serta program pelatihan staf.

c. Mengembangkan sistem dan proses pengelolaan resiko dengan menetapkan indicator kinerja bagi sistem pengelolaan resiko serta penilaian resiko.

d. Mengembangkan sistem pelaporan insiden.

e. Mengembangkan cara berkomunikasi dengan pasien bila terjadi insiden.

f. Mengembangkan sistem analisis terhadap akar penyebab masalah

g. Mengimplementasikan sistem keselamatan pasien yang sudah dibuat

\section{PENUTUP}

Rumah sakit diharapkan bisa mengadakan sosialisasi secara rutin agar menumbuhkan kesadaran dalam pelaksanaan keselamatan pasien. Adanya pembekalan serta sosialisasi terkait keselamatan pasien pada pegawai baru juga perlu ditingkatkan kembali. Perlu dilakukan 
pembekalan juga bagi para kepala ruang sebagai role model atau panutan yang akan memberi contoh yang benar dalam menerapkan sasaran keselamatan perawat.

Selain itu pelaksanaan monitoring serta evalusi diharapkan dilakukan secara rutin dan menyeluruh pada semua unit. Bagi perawat pelaksana agar selalu meningkatkan kesadaran diri serta menumbuhkan kebiasaan dalam melaksanakan sasaran keselamatan pasien sesuai dengan kebijakan yang ada sehingga program keselamatan pasien di rumah sakit bisa berjalan secara maksimal pada semua sasaran keselamatan pasien serta terbentuknya pribadi yang patuh dalam menjalankan aturan yang telah dibuat. Perawat juga diharapkan selalu menyampaikan kendala yang dihadapinya sehingga bisa segera dilakukan perbaikan

Tingkat Pengetahuan Perawat Pengetahuan adalah fakta, keadaan atau kondisi tentang pengertian mencakup kombinasi dari kesadaran sederhana tentang fakta dan pemahaman tentang bagaimana fakta itu berkaitan satu sama lain (Green,1980). Dalam kode etik keperawatan disebutkan bahwa perawat memiliki tanggung jawab agar senantiasa memelihara mutu pelayanan keperawatan yang tinggi disertai kejujuran profesional yang menerapkan pengetahuan serta ketrampilan keperawatan sesuai dengan kebutuhan klien. Dalam hubungannya dengan teman sejawat, perawat berkewajiban melindungi klien dari tenaga kesehatan yang memberikan pelayanan kesehatan secara tidak kompeten, tidak etis dan ilegal.

\section{DAFTAR PUSTAKA}

Budiono, Sumirah B. P. (2015). Konsep dasar keperawatan. Jakarta: Bumi Medika. Dermawan,

Cahyono, Agung. (2015). Hubungan Karakteristik dan Tingkat Pengetahuan Perawat terhadap Pengelolaan Keselamatan Pasien di Rumah Sakit. Jurnal Ilmiah WIDYA, 3(2), 97 - 102.

Herawati, Y. E. (2015) Budaya Keselamatan Pasien Di Ruang Rawat Inap Rumah Sakit X Kabupaten Jember. Jurnal IKESMA. Vol 11 (1) : 54 - 55 
Insani, T.H.N, Sundari, S. (2018) Analisis Pelaksanaan Keselamatan Pasien oleh Perawat. Journal of HealthStudies. Vol. 2 (1) : 85 - 86

Isnaini, N.M, Rofii, (2014) Pengalaman Perawat Pelaksana Dalam Menerapkan Keselamatan Pasien. Jurnal Managemen Keperawatan. Vol. 2 (1) : 31

Ivana, A. Widjasena, B. Jayanti, S. (2014) Analisa Komitmen Manajemen Rumah Sakit (RS) Terhadap Keselamatan Dan Kesehatan Kerja (K3) Pada RS Prima Medika Pemalang. JURNAL KESEHATAN MASYARAKAT Vol. 2 (1) : 36 - 37

Najihah. (2018) Budaya Keselamatan Pasien Dan Insiden Keselamatan Pasien Di Rumah Sakit: Literature Review. JOURNAL OF ISLAMIC NURSING. Vol 3 (1) : 2 - 3

Simamora, R. H., \& Nurmaini, C. T. S. (2019). Knowledge of Nurses about Prevention of Patient Fall Risk in Inpatient Room of Private Hospital in Medan. Indian Journal of Public Health Research \& Development, 10(10), 759-763.

Tukatman, Sulistiawati, Purwaningsih, dkk. (2015) Analisis Keselamatan Dan Kesehatan Kerja Perawat Dalam Penanganan Pasien Di Rumah Sakit Benyamin Guluh Kabupaten Kolaka. Jurnal Ners Vol. 10 (2) : $344-355$

Windyastuti, Hayuna, G.D, Winarti. R (2018) Hubungan Pelaksanaan Timbang Terima Dengan.Keselamatan Pasien Di Ruang Rawat Inap Kelas Iii Rsi Sultan Agung Semarang. Jurnal SMART Keperawatan Sekolah Tinggi Ilmu Kesehatan (STIKes) Karya Husada Semarang. Vol. $5(2): 21-23$

Yarnita, Y. Maswarni (2019) Budaya Keselamatan Pasien Pada Perawat Di Instalasi Perawatan Intensive Rsud Arifin Achmad Provinsi Riau. Jurnal Keperawatan Priority. Vol 2 (2) : 109 110 . 